\title{
Estimation of a closed population size of tadpoles in temporary pond
}

\author{
M. S. C. S. Lima ${ }^{a *}$, J. Pederassib and C. A. S. Souza \\ ${ }^{a}$ Departamento de Biologia, Universidade Federal do Piauí - UFPI, Campus Amilcar Ferreira Sobral, \\ Rodovia BR 343, Km 3,5, CEP 64800-000, Floriano, PI, Brazil \\ ${ }^{\text {b}}$ Departamento de Vertebrados, Museu Nacional, Universidade Federal do Rio de Janeiro - UFRJ, \\ Quinta da Boa Vista, São Cristóvão, CEP 20940-040, Rio de Janeiro, RJ, Brazil \\ 'Instituto de Biologia, Universidade Federal Rural do Rio de Janeiro - UFRRJ, Rodovia BR 465, Km 7, \\ CEP 23890-000, Seropédica, RJ, Brazil \\ *e-mail: slmauro@ufpi.edu.br
}

Received: September 28, 2016 - Accepted: January 13, 2017 - Distributed: May 31, 2018

(With 4 figures)

\begin{abstract}
The practice of capture-recapture to estimate the diversity is well known to many animal groups, however this practice in the larval phase of anuran amphibians is incipient. We aimed at evaluating the Lincoln estimator, Venn diagram and Bayes theorem in the inference of population size of a larval phase anurocenose from lotic environment. The adherence of results was evaluated using the Kolmogorov-Smirnov test. The marking of tadpoles for later recapture and methods measurement was made with eosin methylene blue. When comparing the results of Lincoln-Petersen estimator corresponding to the Venn diagram and Bayes theorem, we detected percentage differences per sampling, i.e., the proportion of sampled anuran genera is kept among the three methods, although the values are numerically different. By submitting these results to the Kolmogorov-Smirnov test we have found no significant differences. Therefore, no matter the estimator, the measured value is adherent and estimates the total population. Together with the marking methodology, which did not change the behavior of tadpoles, the present study helps to fill the need of more studies on larval phase of amphibians in Brazil, especially in semi-arid northeast.
\end{abstract}

Keywords: Amphibia, Anura, capture-recapture, diversity, lentic environments.

\section{Estimativa do tamanho da população fechada de girinos em lagoas temporárias}

\begin{abstract}
Resumo
A prática de captura-recaptura para a estimação da diversidade é bem conhecida para diversos grupos animais, porém na fase larvar de anfíbios anuros essa prática é incipiente. Objetivamos avaliar os métodos do estimador de Lincoln, diagrama de Venn e o teorema de Bayes na inferência do tamanho populacional de uma anurocenose em fase larvar de ambiente lótico. A aderência dos resultados foi avaliada através do teste de Kolmogorov-Smirnov. A marcação dos girinos para posterior recaptura e aferição dos métodos foi feita com eosina de azul de metileno. Ao compararmos os resultados do estimador de Lincoln que corresponde com o do diagrama de Venn e com o teorema de Bayes detectamos diferenças percentuais por amostragem, isto é, a manutenção da proporção dos gêneros de anuros amostrados é mantida entre os três métodos, embora com valores numericamente diferentes. Ao submetermos esses resultados ao teste Kolmogorov-Smirnov não encontramos diferenças significativas. Logo, qualquer que seja o estimador o valor aferido é aderente e estima a população total. Aliado à metodologia de marcação que não alterou o comportamento dos girinos, o presente estudo ajuda a preencher a necessidade de mais estudos na fase larvar dos anfíbios no Brasil, em especial no semiárido nordestino.
\end{abstract}

Palavras-chave: Amphibia, Anura, captura-recaptura, diversidade, ambiente lêntico.

\section{Introduction}

During the decades of 40 and 50 of XX century, the theoretical development for population estimation by capture-recapture of animals was intensified (White et al., 1982). Three approaches explain the main works with population estimators, namely: closed population with simple sampling and the classical sequential capturerecapture, such as the Lincoln estimator (Abuabara and Petrere Junior, 1997; Engen, 1978; Silveira Neto et al., 1976; Otis et al., 1978); Venn diagram (Coeli et al., 2000; Cormack, 1989, 1992; Rivest and Daigle, 2004) and the 
Bayes theorem (Castledine, 1981; King and Brooks, 2001; Leite et al., 2000).

In ecology, the first researcher to employ estimation method was Carl GJ Petersen (1896) by studying the fish migration flow in the Baltic Sea. Frederick Lincoln (1930) estimated the population of wild ducks in North America. There were several published studies that used the capturerecapture with anurans (Hero, 1989; Waichman, 1992; Williamson and Bull, 1996), but studies with tadpoles are still incipient.

Capture-recapture methods are used in various areas, from epidemiology (Coeli et al., 2000) to zoological studies of populations (Fernandez, 1995) or even in the analysis of the variation of measurement intervals of closed communities of diverse magnitudes (Cormack, 1992). The capture-recapture techniques are used for closed populations, where the effects of birth rate or mortality and migration are not taken into account, in this case it is considered no change in population size. They can also be used for open populations, where population changes caused by birth rate, mortality and migration are taken into account (Cormack, 1989).

Tadpoles are especially notable for presenting a wide morphological diversity associated with 46 developmental stages (Altig and McDiarmid, 2007; Gosner, 1960) which requires special study conditions, since the development stage and probability of metamorphosis should be taken into account. Lima and Pederassi (2012) and Lima et al. (2014) showed studies in which the stage progress decreases the probability of mortality, but reduces the population size of the species.

In this work we make the case study of a biocenosis of tadpoles in temporary pond through the mark-recapture method and estimate the closed population size, seeking to establish a method to quantify and understand the sharing of tadpole populations.

\section{Material and Methods}

\subsection{Area of study}

The hydroelectric dam of Boa Esperança is located $80 \mathrm{~km}$ from the city of Guadalupe, State of Piauí, Northeast Brazil with drainage area of $87,500 \mathrm{~m}^{2}$ with spillways with maximum flow of $12,000 \mathrm{~m}^{3} / \mathrm{second}$. On the banks of the dam there are spillways that generate sporadic water flow making temporary ponds during the period of floods occurring between November and March with rainfall peak equivalent to $356 \mathrm{~mm}$ of rain in January.

\subsection{Sampling area and unit}

Temporary pond formed by the spillway water of the dam is located between the coordinates ( $06^{\circ} 44^{\prime} 52.8^{\prime \prime}$; $\left.\mathrm{W} 43^{\circ} 34^{\prime} 39.4^{\prime \prime}\right)$. For 15 minutes three researchers used plastic sieve with $15 \mathrm{~cm}$ handle, measuring $280 \mathrm{~mm}$ $\times 160 \mathrm{~mm} \times 70 \mathrm{~mm}$ with uninterrupted collection and deposition of the tadpoles in a 5 liter plastic container with $160 \mathrm{~mm}$ of diameter. After the collection period we waited the stabilization of the sediments and repeated the same methodology.

\subsection{Capture and recapture}

The collected tadpoles were subjected to eosin methylene blue diluted with water at a ratio of 7.5/1,000, remaining in this solution for 10 minutes, and then they were counted, identified to genus level and released in the same pond. Subsequently, when the pond turbidity was normalized, the procedure was repeated considering the recaptured tadpoles, i.e., colored and new individuals.

There was no change in the animals' behavior during and after the process of marking the tadpoles with eosin methylene blue.

Lincoln Estimator is given by the Equation 1 below:

$\frac{m_{2}}{n_{2}}=\frac{n_{1}}{N} \therefore N=\frac{n_{1 n_{2}}}{m_{2}}$

$\mathrm{N}$ is the population size; $\mathrm{n}_{1}$ is the total number of elements captured in the first sample; $n_{2}$ is the total number of elements captured in the second sample; and $\mathrm{m}_{2}$ is the number of elements captured in the first and second sample (Abuabara and Petrere Junior, 1997; Silveira Neto et al., 1976).

For increased accuracy of the Lincoln-Petersen's estimator it was used the Bailey model (Abuabara and Petrere Junior, 1997; Badii et al., 2012; Bailey, 1951; Fernandez, 1995). Where were used the Equation 2 below:

$N=\frac{n 1(n 2+1)}{m 2+1}$

The standard error of the estimate is given by the Equation 3:

$S E_{N}=\sqrt{\frac{n 1^{2}(n 2+1)(n 2-m 2)}{(m 2+1)^{2}(m 2+2)}}$

The detection of differences between two estimates of population size is measured by the Equation 4 below:

$t_{\text {calc }}=\sqrt{\frac{N_{1}-N_{2}}{\left(S E_{1}\right)^{2}+\left(S E_{2}\right)^{2}}}$

\section{$\mathrm{t}_{\text {calc }}=$ Student's t test}

$\mathrm{N}_{1}$ = estimate of the population size 1

$\mathrm{N}_{2}$ = estimate of the population size 2

$\mathrm{SE}_{1}=$ standard error of the estimate of population size 1 $\mathrm{SE}_{2}=$ standard error of the estimate of population size 2

If $t_{\text {calc }}$ is less than $t_{\text {tabulated }}$ for degrees of freedom $=\alpha$ $\left(\mathrm{t}_{\mathrm{tab}}=1.96\right)$, it is accepted the null hypothesis (the two populations compared do not differ in size). If $t_{\text {calc }}$ is greater than the $t_{\text {tab }}$ for the degrees of freedom $=\alpha$, the null hypothesis is rejected and is assumed that the two compared populations present different sizes (Brower and Zar, 1954). 
To satisfy the result of the $\mathrm{N}_{\mathrm{p}}$ the confidence index (CI) was calculated (Seber, 1982):

a. when the number of individuals marked + number of individuals caught in the second sample was $\geq \mathrm{N}_{\mathrm{p}}$;

b. When the number of individuals marked in the second sample was $>7$.

\section{Axiom for the CI:}

a. When the result of dividing the number of individuals scored in the second sample by the number of individuals caught in the second sample corresponds to $>0.10$ to $<50$ should be used the Poisson distribution, and $>50$ should be used normal approximation to obtain the CI;

b. If the result of the division is $<0.10$ should be used the binomial distribution.

The Equation 5 is used for Normal Approximation:

$$
\frac{n^{2}}{m^{2}}= \pm\left\{\propto\left[\sqrt[2]{\frac{(1-f)\left(1-\frac{n^{2}}{m^{2}}\right)\left(\frac{n^{2}}{m^{2}}\right)}{(c-1)}}\right]+\frac{1}{2 C}\right\}
$$

\section{$\mathrm{f}=$ Population fraction}

$1-\mathrm{f}=$ Correction for finite population

$1 / 2 \mathrm{C}=$ Correction for continuity

$\mathrm{Z} \alpha=$ normalized value to the confidence level of $1-\alpha$.

Venn Diagram (Coeli et al., 2000; Ferreira et al., 2012; Machado et al., 2013 - see Figure 1)

$P A=\frac{n_{a}}{N}:$ probability of being captured in the first sample
$P B=\frac{n_{b}}{N}$ : probability of being captured in the second

sample

$P A B=\frac{n_{c}}{N}:$ probability of being captured in both

samples

Bayes Theorem (Gelman, 2008; Gotelli and Ellison, 2011; Paula et al., 2009)

A genus of tadpole can be collected by three researchers 1, 2 and 3. Considering that the three researchers had the same accuracy of collection, i.e., $50 \%$ efficiency, hypothetical value, and that previous collections corresponded to: $\% \mathrm{sp}_{1}$; b: $\% \mathrm{sp}_{2} ; \mathrm{c}: \% \mathrm{sp}_{3} \ldots \mathrm{n}: \% \mathrm{sp}_{\mathrm{ni}}$ all occupying the same pond. What is the probability of randomly draw out from the pond a particular genus?

Consider the following events:

$\mathrm{G}=$ \{presence of tadpole $\}, \mathrm{P} 1=\{$ Researcher 1$\}$, $\mathrm{P} 2=\{$ Researcher 2$\}$ and $\mathrm{P} 3=\{$ Researcher 3$\}$.

We have, therefore, to calculate using the Equation 6 as below:

$$
\begin{gathered}
P\{G\}=P\{G / P 1\} \cdot P\{P 1\}+ \\
P\{G / P 2\} \cdot P\{P 2\}+P\{G / P 3\} \cdot P\{P 3\} .
\end{gathered}
$$

We know that $\mathrm{P}\left\{\mathrm{P} 1 \% ; \mathrm{P} 2 \% ; \mathrm{P} 3 \%\right.$...PN $\left.{ }_{\mathrm{i}} \%\right\}$ when we apply the Bayes theorem:

Be $A_{1}, A_{2}, A_{3}, \ldots, A_{n}, n$ mutually exclusive events, as shown in Equation 7 below, we have:

$$
P\left\{A_{i}\right\}=\frac{P\left\{A_{i}\right\} \cdot P\left\{B / A_{i}\right\}}{P\left\{A_{1}\right\} \cdot P\left\{B / A_{1}\right\}+P\left\{A_{2}\right\} \cdot P\left\{B / A_{2}\right\}+\ldots+P\left\{A_{n}\right\} \cdot P\left\{B / A_{n}\right\}}
$$

Replacing $\mathrm{B}$ by genus and $\mathrm{A}_{\mathrm{i}}$ by researcher, we ask the question:

Considering that $\mathrm{P} 1, \mathrm{P} 2$ and $\mathrm{P} 3$ constitute a partition of the sample space, what is the possibility of obtaining the four genera in a sample?

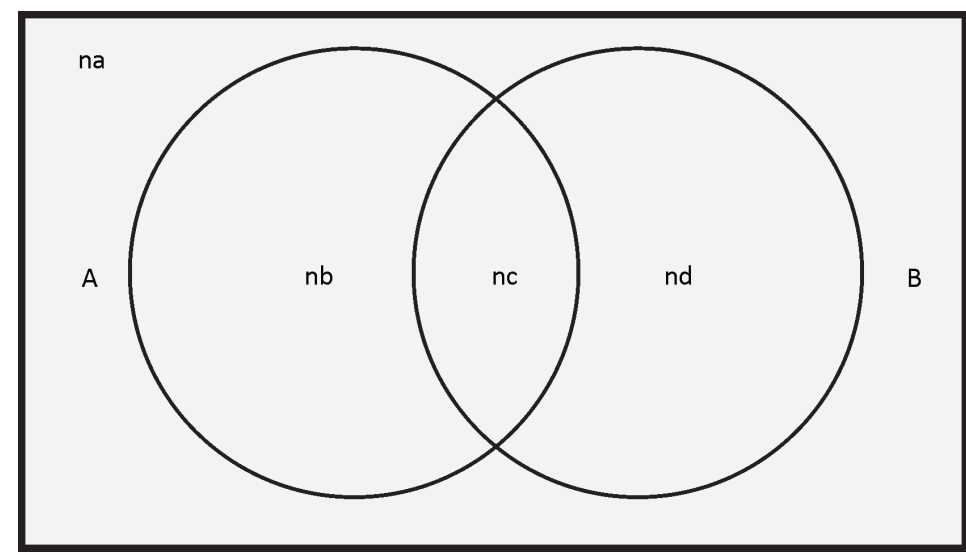

Figure 1. Schematization of the Venn diagram. Sample $N$ sizes $=n_{a}+n_{b}+n_{c}+n_{d}$; sample $A=\left(N_{A}=n_{b}+n_{c}\right)$; sample $\mathrm{B}=\left(\mathrm{N}_{\mathrm{B}=} \mathrm{n}_{\mathrm{d}}+\mathrm{n}_{\mathrm{c}}\right) \cdot \mathrm{n}_{\mathrm{a}}=$ number of non-captured tadpoles in any sample; $\mathrm{n}_{\mathrm{b}}=$ number of captured tadpoles in the first sample; $\mathrm{n}_{\mathrm{c}}=$ number of captured tadpoles in the first and second sample; $\mathrm{n}_{\mathrm{d}}=$ number of captured tadpoles in the second sample. 


\subsection{Area and volume of the sample space}

The area and volume of the pond were obtained through the half ellipse, in which the area is equal to the greatest length $(\mathrm{C})$; greatest width $(\mathrm{L})$ and greatest depth (p): $\mathrm{A}=(\mathrm{C} \times \mathrm{L} \times \mathrm{p}) / 2$ and the volume is equal to $\mathrm{V}=4 / 3 \mathrm{p}((\mathrm{C} / 2+\mathrm{L} / 2+\mathrm{p}) / 3)^{3} / 2$.

\subsection{Occupation and density}

The frequency of dominance and relative dominance correspond to the number of specimens of a species by the total number of specimens of the total sampled. The density was calculated using the absolute population by the area.

\subsection{Diversity index (Zar, 2010)}

Brillouin Index is obtained by the Equation 8 below:

$$
H B=\frac{\ln N !-\sum \ln _{i} !}{N}
$$

$\mathrm{N}=$ Total number of specimens of the total sampled $\mathrm{n}=$ Number of specimens of a species.

The approximation of the factorial of a number was calculated by spreadsheet according to Lima and Batista (2010).

The adherence of the estimators was evaluated using the Kolmogorov-Smirnov test.

\section{Results}

Three hundred tadpoles distributed in four genera were collected: Scinax, Leptodactylus, Pithecopus and Pseudopaludicola. When we submitted the data of the first and second counting of tadpoles to the Lincoln-Petersen estimator, we concluded that the total population corresponded to 1,130 tadpoles, being $51.56 \%$ of Scinax sp., $18.78 \%$ of Leptodactylus sp., 3.13\% of Pithecopus sp. and $26.51 \%$ of Pseudopaludicola sp., corresponding to the distribution density of 130.18 tadpoles per square meter. The Standard
Error (SE) was 62.19 and 60.95 , being the differences lower than the tabulated $\alpha(0.94)$. The confidence index (Normal Approach) at 95\% was 16.15 (inferior limit), and 39.12 (superior limit).

By using the descriptors of the Venn diagram (see Figure 2) we identified the intersection of 173 tadpoles, being 473 tadpoles considered to the first sample and 525 tadpoles to the second sample. When we estimate the probability of tadpoles by genus and sample, we have in the first sample $33.95 \%$ of Scinax sp., 9.77\% of Leptodactylus sp., $1.51 \%$ of Pithecopus sp., and $12.71 \%$ of Pseudopaludicola sp.; in the second sample $20 \%$ of Scinax sp., $2.66 \%$ of Leptodactylus sp., $0.44 \%$ of Pithecopus sp., and 3.55\% of Pseudopaludicola sp. As intersection, i.e., estimated as present in both samples, we have $12 \%$ of Scinax sp., $1.77 \%$ of Leptodactylus sp., $0.17 \%$ of Pithecophus sp., and $1.42 \%$ of Pseudopaludicola sp. (see Figure 3).

Considering that the three researchers had the same accuracy of collection, i.e., 50\% efficiency (hypothetical value), and that previous collections corresponded to: $33 \%$ in Scinax sp. (S); 9.7\% in Leptodactylus sp. (L); $1.5 \%$ in Pithecopus sp. (PH), and $12.7 \%$ in Pseudopaludicola sp. (PS) all occupying the same pond. What is the probability of randomly draw out from the pond a specimen of a particular genus?

Consider the following events:

$\mathrm{G}=$ \{presence of tadpole $\}, \mathrm{P} 1=\{$ Researcher 1$\}$, $\mathrm{P} 2=\{$ Researcher 2$\}$ and P3 $=\{$ Researcher 3$\}$.

We have, therefore, to calculate using the Equation 6: $\mathrm{P}\{\mathrm{G}\}=\mathrm{P}\{\mathrm{G} / \mathrm{P} 1\} . \mathrm{P}\{\mathrm{P} 1\}+\mathrm{P}\{\mathrm{G} / \mathrm{P} 2\} . \mathrm{P}\{\mathrm{F} 2\}+\mathrm{P}\{\mathrm{G} / \mathrm{P} 3\} . \mathrm{P}\{\mathrm{P} 3\}$.

We know that $\mathrm{P}\{\mathrm{P} 1\}=1 / 2 ; \mathrm{P}\{\mathrm{P} 2\}=1 / 2$, and $\mathrm{P}\{\mathrm{P} 3\}$ $=1 / 2$ and we also know that $\mathrm{P}\{\mathrm{G} / \mathrm{S}\}=0.33 ; \mathrm{P}\{\mathrm{G} / \mathrm{L}\}$ $=0.09 ; \mathrm{P}\{\mathrm{G} / \mathrm{PH}\}=0.015$ and $\mathrm{P}\{\mathrm{G} / \mathrm{PS}\}=0.12$. Applying these values to the expression above (Equation 6), we find:

$\mathrm{P}\{\mathrm{G}\}=(0.33) \cdot(0.5)+(0.09) \cdot(0.5)+(0.015) \cdot(0.5)$ $+(0.12) .(0.5)=0.165+0.045+0.0075+0.06=0.27$, i.e., $27 \%$.

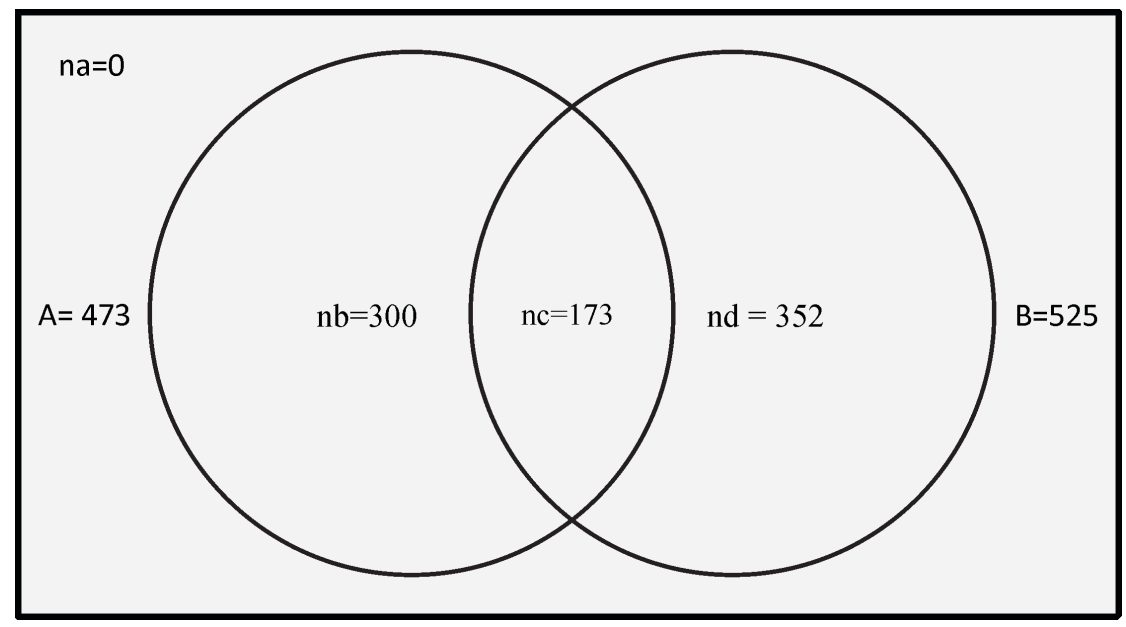

Figure 2. Venn diagram; (A) First Sample; (B) Second Sample, nb tadpoles captured in the first sample, nc tadpoles coincident in both samples, nd tadpoles captured in the second sample. 
In a sample the probability of presence of each of the four genera is: Scinax sp. $=70 \%$; Leptodactylus $\mathrm{sp}$. $=27 \%$; Pseudopaludicola $\mathrm{sp} .=2.7 \%$; Pithecopus $\mathrm{sp} .=0 \%$

By submitting the results to the Kolmogorov-Smirnov test no significant differences were found (see Table 1), what shows that no matter the proposed estimator, i.e., Lincoln-Petersen, Venn or Bayes, the measured value is adherent and estimates the total population.

When comparing the results of Lincoln-Petersen estimator corresponding to the Venn diagram and Bayes theorem, we detected percentage differences per sampling (see Figure 4), i.e., the proportion of the genera is kept among the three methods, however the values are different.

The Brillouin diversity index was 0.136123 .

\section{Discussion}

In our case, the community is closed for having as a physical limiter the own pond with an area of $8.68 \mathrm{~m}^{2}$ and $9,487 \mathrm{ml}$ of water. Studies on fish in streams have been developed demonstrating that it is possible to estimate

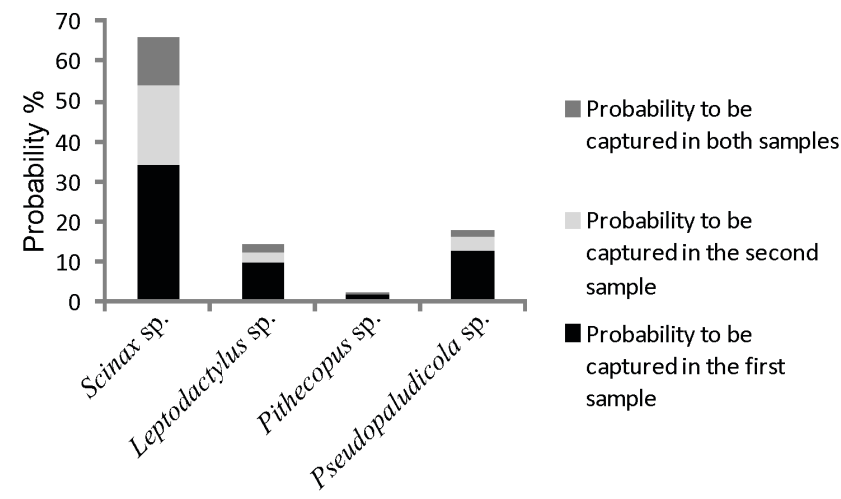

Figure 3. Populations of tadpoles based on descriptors of the Venn diagram according to the temporal sampling.

Table 1. Values for the Kolmogorov-Smirnov sampled by genus.

\begin{tabular}{|c|c|c|c|c|}
\hline \multirow{2}{*}{ Sample } & Pithecopus sp. & Pseudopaludicola sp. & Leptodactylus sp. & Scinax sp. \\
\hline & 4 & 4 & 4 & 4 \\
\hline Maximum deviation & 0.2500 & 0.2500 & 0.2660 & 0.2149 \\
\hline Unilateral critical value $(0.05)$ & 0.5650 & 0.5650 & 0.5650 & 0.5650 \\
\hline Unilateral critical value $(0.01)$ & 0.6890 & 0.6890 & 0.6890 & 0.6890 \\
\hline $\mathrm{p}$ (value) unilateral & ns & ns & ns & ns \\
\hline Bilateral critical value $(0.05)$ & 0.6240 & 0.6240 & 0.6240 & 0.6240 \\
\hline Bilateral critical value $(0.01)$ & 0.7340 & 0.7340 & 0.7340 & 0.7340 \\
\hline $\mathrm{p}$ (value) bilateral & ns & ns & ns & ns \\
\hline
\end{tabular}

ns = non significant.

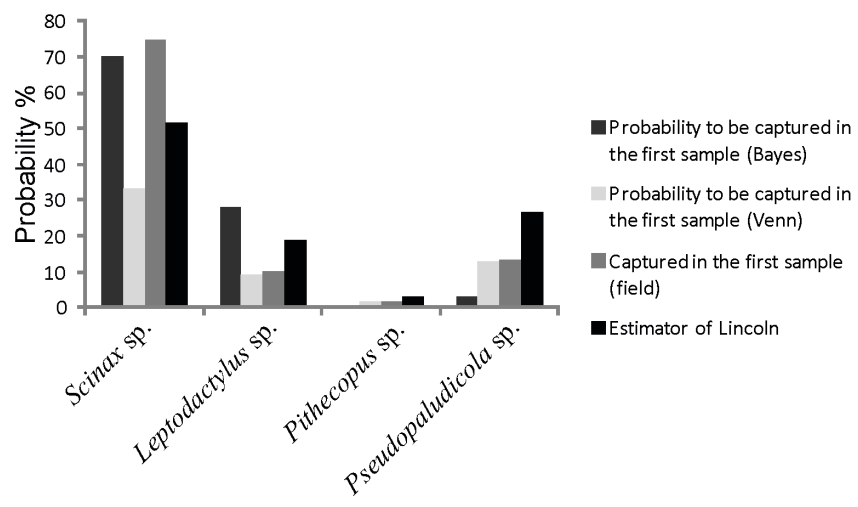

Figure 4. Comparison of the estimators of Lincoln; Bayes theorem and Venn diagram. 
populations in water bodies, in this case the population was open making the estimation difficult (Suzuki et al., 2010), unlike studies on tadpoles in lentic environments, where it is possible to control some parameters that directly influence the population size, i.e., emigration and immigration (Abrunhosa et al., 2006), apart from that, the short interval of the study is not influenced by mortality or birth. In northeastern Brazil, where most of the water bodies are temporary (Santos, 2009), the capture-recapture estimation method can be an important tool in the study of anurocenose (Duellman and Trueb, 1994).

We used the Brillouin index to calculate the diversity, because it is a robust index since it has no variance, and no statistical test is necessary to demonstrate significant differences (Magurran 1988, 2011). Furthermore, it is recommended to use this index when the communities are known, and that is why it is used to measure closed diversity, as the parasitic ones (Alves and Luque, 2006; Chaves and Luque, 1999; Luque et al., 2008; Paraguassú and Luque, 2007). If we consider that the community is known in this study because of the limitations in the area of dispersion of populations of Scinax sp.; Leptodactylus sp.; Pseudopaludicola sp.; Pithecopus sp., we conclude that the index is ideal for measuring diversity in temporary ponds, which corresponded to 0.136123 in this study. According to Peet (1974) the mathematical assumption must be between $\mathrm{N} / \mathrm{S} \leq 1.44$ e $X \leq 0.05$ which correspond to the results found in this study.

The Lincoln-Petersen estimator is considered the simplest of population estimates descriptors; the axioms that the model is linked are: (a) closed population - during all research the population remains unchanged; (b) all animals have the same probability of capture in the first sample; (c) the marks do not affect the animal; (d) the second sample is random; (e) during the interval between the samples the animals remain marked (Abuabara and Petrere Junior, 1997; Badii et al., 2012; Krebs, 1989).

Despite the simplicity of the mathematical model of the Lincoln-Petersen estimator, this original equation is the basis for several other estimators with greater complexity, and its mathematical simplicity meets the axiom (Fernandez, 1995). Furthermore, this model when combined becomes robust, and with low bias (Alpizar-Jara and Pollock, 1996).

The Lincoln-Petersen estimator tends to overestimate the population when the sample is small; according to Krebs (1989) that bias can be minimized when the number of trapped animals is greater than seven. In this study, the lowest sample corresponded to 40 individuals, whose recaptured tagged totaled 16 specimens; therefore, it eliminates the bias of overestimation of the population. Begon (1979) believes that the bias can be avoided with the use of a modification of the estimator proposed by Bailey (1951), and ensures more accurate the results. In this case, it was clear that the higher the value $\mathrm{m}_{2}$, the lower the value of $\mathrm{N}$. When $\mathrm{m}_{2}$ is small or equal to zero, $\mathrm{N}$ is infinite. Therefore, the estimator Lincoln-Petersen shows infinite expectancy and variance. After the modification of the estimator Lincoln-Petersen by Chapman (1951), and Bailey (1951), the average and variance become finite (Abuabara and Petrere Junior, 1997; Zanzini, 2008).

The standard error was 62.19 and 60.95 , being the differences lower than the tabulated $\alpha(0.94)$, thus the population calculated between the two estimators (Lincoln-Petersen, and Bailey) do not differed in size. This result reinforces the understanding according to Krebs (1989).

The precision of the Venn descriptors in the model of two samples is coupled to the sample size A n1 and the sample size B n2 (Wittes, 1972). If the relationship between $\mathrm{n} 1$ and $\mathrm{n} 2$ is too small, the estimation of Ne will show an unacceptable error (Jolly, 1982). In this case, the value of the samples should be raised in the way that the value of Ne approach to the real value of N (Dunn and Andreoli, 1994). In this study, the difference between the first and the second sample corresponded to $10 \%$, and according to Wittes (1972) to satisfy the value of $\mathrm{Ne}$, in relation to the real value of $\mathrm{N}$, the sum of $\mathrm{n} 1$ and $\mathrm{n} 2$ should correspond to $5 \%$ of $\mathrm{N}$, at least. Therefore, in the present study, the diagram of Venn, according to the sampled values higher than the minimum, attend to the recommended axiom.

There is no a capture-recapture process if it is not observed a marked animal during the sample (Silveira Neto et al., 1976). As observed, the estimator of Lincoln-Petersen do not exist when $\mathrm{m}=0$. In contrast, the estimator of Bailey (1951) tends to zero when $m$ tends to zero. Therefore, in the Bayesian focus, the a priori knowledge of the population size, in relation to the proportion of the genus of anuran larvae, as well as the probability $\mathrm{P}=\left(\mathrm{P}_{1 ;} \mathrm{P}_{2 ; \ldots} \mathrm{P}_{\mathrm{n}}\right)$ of larvae capture, being $\mathrm{S} \geq 2$ the sampling time intervals was the theoretic applied herein to the Bayes theorem. This prior information is a priori distribution of the parameters of Bayesian model, and when no information is available, we can use an a priori uninformative distribution to $\mathrm{P}$ and N (Smith, 1991).

Considering the a priori knowledge provided by classical models developed here, as well the Venn diagram, the measured values were the a priori values applied in the Bayes theorem (Smith, 1991; Tierney and Kadane, 1986). Garthwaite et al. (1995) established that the criteria to be adopted for the choice of the prior distribution for Bayesian model can be constituted by non-informative knowledge, since the sample size is known. In this case, we consider the sample size proportions calculated by the classical and Venn methods developed in this study.

For Garthwaite et al. (1995) the corollary to two assumptions should be considered: (i) the probability of capture to a particular animal is the same in each sample, which implies that samples are taken under identical and controlled conditions. For this first corollary the conditions are met in materials and methods through the description of the method in the sample unit; (ii) the catch will be identical 
and independent, with a known distribution, thus we have to have a good idea of the sampling distribution of the probability of capture. Therefore, through the estimators previously calculated the proportion of the genus Scinax sp., Leptodactylus sp., Pithecopus sp., and Pseudopaludicola sp. were maintained, occurring only quantitative variation in each method, that do not represent significant difference according to the Kolmogorov-Smirnov test.

A combination of methods to estimate the population increases strength and reduces the bias of the results (Alpizar-Jara and Pollock, 1996; Pollock, 1991). In the case of an animal presents less chance of being caught, considering all samples, Ne can be calculated for each group and then add the estimates, i.e., when an animal is more likely to be captured in a sample than in another, we may combine the two estimates to determine one (Sekar and Deming, 1949).

The three tested estimators achieved the same level of effectiveness in measuring population size, representing important tools for the study of diversity, quantification and sharing of lentic environments by populations of tadpoles. Together with the marking methodology, which did not change the behavior of tadpoles, the present study helps to fill the need of more studies on larval phase of amphibians in Brazil, especially in its semi-arid northeast.

\section{Acknowledgements}

We thank to ICMBIO/SISBIO for the authorization \# 38.966-2 relative to collection.

\section{References}

ABRUNHOSA, P.A., WOGEL, H. and POMBAL JUNIOR, J.P., 2006. Anuran temporal occupancy in a temporary pond from the Atlantic Rain Forest, south-eastern Brazil. The Herpetological Journal, vol. 16, pp. 115-122.

ABUABARA, M.A.P. and PETRERE JUNIOR, M., 1997. Estimativas da abundância de populações animais: introdução às técnicas de marcação e recaptura. Maringá: EDUEM. 129 p.

ALPIZAR-JARA, R. and POLLOCK, K.H., 1996. A combination line transect and capture-recapture sampling model for multiple observers in aerial surveys. Journal of Environmental Ecology and Statistics, vol. 3, no. 4, pp. 311-327. http://dx.doi.org/10.1007/ BF00539369.

ALTIG, R. and MCDIARMID, R.W., 2007. Morphological diversity and evolution of egg and clutch structure in amphibians. Herpetological Monograph, vol. 21, no. 1, pp. 1-32. http://dx.doi. org/10.1655/06-005.1.

ALVES, D.R. and LUQUE, J.L., 2006. Ecologia das comunidades de metazoários parasitos cinco espécies de escombrídeos (Perciformes; Scrombidae) do litoral do estado do Rio de Janeiro Brasil. Revista Brasileira de Parasitologia Veterinária, vol. 15, no. 4, pp. 167-181. PMid:17196121.

BADII, M.H., GUILLEN, A., LANDEROS, J., CERNA, E., OCHOA, Y. and VALENZUELA, J., 2012. Muestreo por Métodos de Captura-Recaptura (Sampling via Capture-Recapture Methods).
Daena. International Journal of Good Conscience, vol. 7, no. 1, pp. 97-131.

BAILEY, N.T.J., 1951. On estimating the size of mobile populations from recapture data. Biometrika, vol. 38, no. 3-4, pp. 293-306. http://dx.doi.org/10.1093/biomet/38.3-4.293.

BEGON, M., 1979. Investigating animal abundance: capturerecapture for biologists. London: Edward Arnold. $97 \mathrm{p}$.

BROWER, J.E. and ZAR, J.H., 1954. Field and laboratory methods for general ecology. Dubuque: Wm.C. Brow Publishers. 226 p.

CASTLEDINE, B.A., 1981. Bayesian analysis of multiplerecapture sampling for a closed population. Biometrika, vol. 67, no. 1, pp. 197-210. http://dx.doi.org/10.1093/biomet/68.1.197.

CHAPMAN, D.G., 1951. Some properties of the hypergeometric distribution with applications to zoological sample censures. University of California Publications in Statistics, vol. 1, pp. 131-160.

CHAVES, N.N. and LUQUE, J.L., 1999. Ecology of metazoans parasites of Menticirrhus americanus (Osteichthyes: Sciaenidae), coast area from Rio de Janeiro State, Brazil. Revista Brasileira de Parasitologia Veterinária, vol. 8, no. 2, pp. 137-144.

COELI, C.M., VERAS, R.P. and COUTINHO, E.S.F., 2000. Metodologia de captura-recaptura: uma opção para a vigilância das doenças não transmissíveis na população idosa. Cadernos de Saúde Pública, vol. 16, no. 4, pp. 1071-1082. PMid:11175530. http://dx.doi.org/10.1590/S0102-311X2000000400025.

CORMACK, R.M., 1989. Log-linear models for capturerecapture. Biometrics, vol. 45, no. 2, pp. 395-413. http://dx.doi. org/10.2307/2531485.

CORMACK, R.M., 1992. Interval estimation for mark-recapture studies of closed populations. Biometrics, vol. 48, no. 2, pp. 567-576. PMid:1637979. http://dx.doi.org/10.2307/2532310.

DUELLMAN, W.E. and TRUEB, L., 1994. The biology of amphibians. Maryland: Johns Hopkins University Press. 670 p.

DUNN, J. and ANDREOLI, S.B., 1994. Método de captura e recaptura: nova metodologia para pesquisas epidemiológicas. Revista de Saúde Pública, vol. 28, no. 6, pp. 449-453. PMid:7660051. http://dx.doi.org/10.1590/S0034-89101994000600009.

ENGEN, S.,1978. Stochastic abundance models. New York: Chapman and Hall. 125 p. http://dx.doi.org/10.1007/978-94009-5784-8.

FERNANDEZ, F.A.S., 1995. Métodos para estimativas de parâmetros populacionais por captura, marcação e recaptura. In: P.R. PERES-NETO, J.L. VALENTIN and F.A.S. FERNANDEZ, eds. Programa de pós-graduação em ecologia. Rio de Janeiro: Instituto de Biologia, UFRJ, pp. 1-26. http://dx.doi.org/10.4257/ oeco.1995.0201.01.

FERREIRA, E.B., MILITANI, M.V.B. and DUARTE, V.P., 2012. Estimação do tamanho de população em um cultivo de tilápia (Oreochromis niloticus) via captura-marcação-recaptura. Revista Universidade Vale do Rio Verde, vol. 10, no. 1, pp. 246-254. http:// dx.doi.org/10.5892/ruvrv.2012.101.246254.

GARTHWAITE, P.H., YU, K. and HOPE, P.B., 1995. Bayesian analysis of multiple recapture model. Communication in Statistics and Mathematics, vol. 24, no. 9, pp. 2229-2247. http://dx.doi. org/10.1080/03610929508831613. 
GELMAN, A., 2008. Objections to Bayesian statistics. Bayesian Analysis, vol. 3, no. 3, pp. 445-450. http://dx.doi.org/10.1214/08BA318.

GOSNER, K.L., 1960. A simplified table for staging anuran embryos and larvae with notes on identification. Herpetologica, vol. 16, pp. 183-190.

GOTELli, N.J. and ELlisOn, A.M., 2011. Principios de estatística em ecologia. Porto Alegre: Artmed. 528 p.

HERO, J.M., 1989. A simple code for toe clipping anurans. Herpetological Review, vol. 20, pp. 66-67. http://dx.doi.org/10.1371/ journal.pbio.0020351

JOLLY, G.M., 1982. Mark-recapture models parameters constant in time. Biometrics, vol. 38, no. 2, pp. 301-321. PMid:7115864. http://dx.doi.org/10.2307/2530445.

KING, R. and BROOKS, S.P., 2001. On the Bayesian analysis of population size. Biometrika, vol. 88, no. 2, pp. 317-336. http:// dx.doi.org/10.1093/biomet/88.2.317.

KREBS, C.S., 1989. Ecology: the experimental analysis of distribution and abundance. New York: Harper and Row. 688 p.

LEITE, J.G., RODRIGUES, J. and MILAN, L.A., 2000. A Bayesian analysis for estimating the number of species in a population using non homogeneous Poisson process. Statistics \& Probability Letters, vol. 48, no. 2, pp. 153-161. http://dx.doi. org/10.1016/S0167-7152(99)00198-4.

LIMA, M.S.C.S. and BATISTA, J.R.L., 2010. Rotina matemática para o cálculo do logaritmo do fatorial de um número inteiro e seu uso no cálculo do índice de diversidade de Brillouin. Revista Brasileira de Zoociências, vol. 12, no. 3, pp. 305-310.

LIMA, M.S.C.S. and PEDERASSI, J., 2012. Morphometrics and ratio of body proportionality of tadpoles of Rhinella icterica (Anura, Bufonidae) at different developmental stages. Brazilian Journal of Biology $=$ Revista Brasileira de Biologia, vol. 72, no. 3, pp. 623-629. PMid:22990836. http://dx.doi.org/10.1590/ S1519-69842012000300028.

LIMA, M.S.C.S., PEDERASSI, J. and SOUZA, C.A.S., 2014. Longevity and survival curves of Rhinella icterica (Anura, Bufonidae) under laboratory conditions. Brazilian Journal of Biology $=$ Revista Brasileira de Biologia, vol. 74, no. 2, pp. 438443. PMid:25166328. http://dx.doi.org/10.1590/1519-6984.02512.

LINCOLN, F.C., 1930. Calculating waterfowl abundance on the basis of banding returns. Washington: U.S. Department of Agriculture, pp. 1-8. Circular, no. 118.

LUQUE, J.L., FELIZARDO, N.N. and TAVARES, L.E.R., 2008. Community ecology of the metazoan parasites of namorado sandperches, Pseudopercis numida Miranda-Ribeiro, 1903 and P. semifasciata Cuvier, 1829 (Perciformes: Pinguipedidae), from the coastal zone of the State of Rio de Janeiro, Brazil. Brazilian Journal of Biology, vol. 68, no. 2, pp. 269-278. PMid:18660954. http://dx.doi.org/10.1590/S1519-69842008000200007.

MACHADO, P.P., KRAEMER, M.V.S., KLIEMANN, N., GONZÁLEZ-CHICA, D.A. and PROENÇA, R.P.C., 2013. Relação entre porção, medida caseira e presença de gordura trans em rótulos de produtos alimentícios. Mundo da Saúde, vol. 37, no. 3, pp. 299-311

MAGURRAN, A.E., 1988. Ecological diversity and its measurement. New Jersey: Princeton University Press. 192 p. http://dx.doi. org/10.1007/978-94-015-7358-0.
MAGURRAN, A.E., 2011. Medindo a diversidade biológica. Paraná: UFPR. 262 p.

OTIS, D.L., BURNHAM, K.P., WHITE, G.C. and ANDERSON, D.R., 1978. Statistical inference from capture data on closed animal populations. Wildlife Monographs, vol. 62, pp. 1-135.

PARAGUASSÚ, A. and LUQUE, J.L., 2007. Metazoários parasitos de seis espécies de peixes do reservatório de Lajes, Estado do Rio de Janeiro, Brasil. Revista Brasileira de Parasitologia Veterinária, vol. 16, no. 3, pp. 121-128. PMid:18078597. http:// dx.doi.org/10.1590/S1984-29612007000300002.

PAULA, M., ALMEIDA, G.O. and GUEDES, A.C.S., 2009. O uso das distribuições Poisson e Gama na estimação do tamanho populacional animal via modelo Bayesiano. Revista Cientifica da UFPA, vol. 7, no. 1, pp. 1-17.

PEET, R.K., 1974. The measurement of species diversity. Annual Review of Ecology Evolution and Systematics, vol. 5, no. 1, pp. 285-307. http://dx.doi.org/10.1146/annurev.es.05.110174.001441.

PETERSEN, C.G.J., 1896. The yearly immigration of young plaice into Limfjord from the German sea. Report of the Danish Biological Station, vol. 6, pp. 1-48.

POLLOCK, K.H., 1991. Modeling capture, recapture, and removal statistics fish and wild life population; past, present and future. Journal of the American Statistical Association, vol. 86, pp. 2538. http://dx.doi.org/10.2307/2289733.

RIVEST, L.P. and DAIGLE, G., 2004. Log linear models for the robust design in mark recapture experiments. Biometrics, vol. 60, no. 1, pp. 100-107. PMid:15032779. http://dx.doi. org/10.1111/j.0006-341X.2004.00157.x.

SANTOS, E.M., 2009. Notas sobre predação de anuros em uma poça temporária no nordeste do Brasil. Boletim do Museu de Biologia Mello Leitão, vol. 25, pp. 77-82.

SEBER, G.A.F., 1982. The estimation of animal abundance and related parameters. New York: Macmillan. $654 \mathrm{p}$.

SEKAR, C.C. and DEMING, W.E., 1949. On method of estimating birth and death rates, and the extent of registration. Journal of the American Statistical Association, vol. 44, no. 245, pp. 10-15. http://dx.doi.org/10.1080/01621459.1949.10483294.

SILVEIRA NETO, S.S., NAKANO, O., BRABIN, D. and VILLA-NOVA, N.A., 1976. Manual de ecologia dos insetos. São Paulo: Ceres. 419 p.

SMITH, P.J., 1991. Bayesian analysis for a multiple capturerecapture model. Biometrika, vol. 78, no. 2, pp. 399-408. http:// dx.doi.org/10.1093/biomet/78.2.399.

SUZUKI, F.M., ZAMBALDI, L.P. and POMPEU, P.S., 2010. Uso de marcação e recapture para estimar a abundância e densidade de Trichomycterus brasiliensis (Siluriformes, Trichomycteridae) em porções do córrego da Bexiga, Carrancas, Minas Gerais, Brasil. Boletim do Museu de Biologia Mello Leitão, vol. 28, pp. 89-104.

TIERNEY, L. and KADANE, J.B., 1986. Accurate Approximations for Posterior Moments and Marginal Densities. Journal of the American Statistical Association, vol. 81, no. 393, pp. 6-8. http:// dx.doi.org/10.1080/01621459.1986.10478240.

WAICHMAN, A.V., 1992. An alphanumeric code for toe clipping amphibians and reptiles. Herpetological Review, vol. 23, pp. 19-21. 
WHITE, G.C., ANDERSON, D.R., BURTHAM, K.P. and OTIS, D.L., 1982. Capture-recapture and removal methods for sampling closed populations. Los Alamos: Los Alamos National Laboratory. 235 p.

WILLIAMSON, I. and BULL, C.M., 1996. Population ecology of the Australian frog Crinia signifera: adults and juveniles. Wildlife Research, vol. 23, no. 3, pp. 249-266. http://dx.doi. org/10.1071/WR9960249.
WITTES, J., 1972. On the bias and estimated variance of Chapman's two-sample capture-recapture population estimate. Biometrics, vol. 28, no. 2, pp. 7-59. http://dx.doi.org/10.2307/2556173.

ZANZINI, A.C.S., 2008. Levantamento, análise e diagnóstico da fauna de pequenos, médios e grandes mamíferos em estudos ambientais. Minas Gerais: UFLA/FAEP.

ZAR, J.H., 2010. Biostatistical analysis. 5th ed. New Jersey: Pearson. 944 p. 